Wijerathna, B.V.M.K. and Abeynayake, M.D.T.E., 2021. Challenges and issues of environmental protection instruments related to infrastructure development projects in Sri Lanka. In: Sandanayake, Y.G., Gunatilake, S. and Waidyasekara, K.G.A.S. (eds). Proceedings of the $9^{\text {th }}$ World Construction Symposium, 9-10 July 2021, Sri Lanka. [Online]. pp. 171-182. DOI: https://doi.org/10.31705/WCS.2021.15. Available from: https://ciobwcs.com/papers/

\title{
CHALLENGES AND ISSUES OF ENVIRONMENTAL PROTECTION INSTRUMENTS RELATED TO INFRASTRUCTURE DEVELOPMENT PROJECTS IN SRI LANKA
}

\author{
B.V.M.K. Wijerathna ${ }^{1}$ and M.D.T.E. Abeynayake ${ }^{2}$
}

\begin{abstract}
The construction industry is required to improve sustainability to increase the rapid growth of the economy of Sri Lanka. The Central Environmental Authority (CEA) has introduced Environmental Impact Assessment (EIA) survey, Initial Environmental Examination (IEE), and Environmental Protection License (EPL) as environmental protection instruments that have been correlated with construction projects. To interrupt the smooth performance of the EIA, IEE, and EPL, many challenges have been associated with these procedures. The research problem was approached through six preliminary interviews to refine the identified challenges and issues related to EIA, IEE and EPL with their processes within the Sri Lankan context. Based on the preliminary interview results, forty questionnaires were distributed to investigate the level of significance of the challenges and issues with regard to EIA, IEE, and EPL related to development projects. For this research, mixed research approach is used. Collected data were analysed in terms of statistical analysis and content analysis using NVivo 12 software respectively. The analysed data were revealed different issues of EIA, IEE, and EPL instruments in Sri Lanka. Especially challenges related to regulatory bodies were identified. According to the research, there were many adverse effects due to the ineffective implementation of environmental protection regulatory instruments. Similarly, it revealed that issues were affected to the time, cost, and quality of the construction projects. Ultimately, it provided proper guidance for implementing EIA, IEE, and EPL instruments and the necessity of implementation of a post-monitoring mechanism for environmental protection instruments.
\end{abstract}

Keywords: Environmental impact assessments; Environmental instruments; Environmental issues; Environmental protection.

\section{INTRODUCTION}

Development projects support people to meet social needs and affect the economic growth of a country (Abidin, 2010). To achieve expressive growth in the economy, developing countries must promote infrastructure development projects (Lenferink et al., 2013). Traditional constructions and designs focus only on their time, cost, and quality

\footnotetext{
${ }^{1}$ Department of Building Economics, University of Moratuwa, Sri Lanka, bvmkalhara@gmail.com

${ }^{2}$ Department of Building Economics, University of Moratuwa, Sri Lanka, mabeynayake@uom.lk
} 
and, little attention is paid to environmental impacts (Ofori, 1990). Infrastructure development projects are considered the most environmentally unfriendly human activity among various kinds of construction activities ( $\mathrm{Gu}$ and Sheate, 2010). Sustainable Developments addresses the integration of triple bottom line principles within the Social, Environmental and Economic dimensions of sustainable construction (Fugar and Agyakwah-Baah, 2017). Proper environmental protection instruments lead to manage the environmental impacts of construction projects, by minimising the unexpected delays, reducing the cost of construction, and assisting in considering a range of measures onsite by determining the major environmental impacts towards sustainable developments (Gangolells et al., 2009). In Sri Lanka, Environmental Impact Assessment survey (EIA), Initial Environmental Examination (IEE), Environmental Protection Licensing (EPL) are the major environmental protection regulatory instruments that are available to regulate environmental impacts of Construction projects (Samarakoon and Rowan, 2008). EIA is applicable for mega-development projects and IEE for minor development projects by enforcing the National Environment Act (NEA), and EPL for all construction activities published in the Gazette No.1533/16 dated 25.01.2008 (Zubair, 2001). The effective implementation of EIA, IEE, and EPL procedures is impeded mainly by challenges and issues in Sri Lanka (Kodituwakku, 2010).

EIA, IEE, and EPL are important environment management and regulation tools, which have been established to mitigate the negative impacts and increase the positive impacts to the environment and the general public, which occurs due to construction and development activities (Bradley and Swaddling, 2018). The effectiveness of the implementation of environmental impact assessment procedures often remains a challenge (Cashmore et al., 2015). They are weaknesses in several EIA, IEE, and EPL practices, lack of provisions for EIA, IEE assessments, weak compliance monitoring, insufficient quality control exercised over EIA reports, deficiencies in the government and lack of expertise involvement, challenges due to political and economic influences etc (Bradley and Swaddling, 2018). In Sri Lanka, the entire EIA process is bypassed by some developers through various kinds of unauthorised pathways (Zubair, 2001). It was found that there was a limited number of research on the challenges of implementing environmental protection regulatory instruments such as EIA, IEE, and EPL in the Sri Lankan context. Owing to the absence of proper information, this research seeks out to address this gap by exploring the challenges and issues of environmental protection instruments and to make recommendations for the effective implementation of EIA, IEE, and EPL for infrastructure development projects in Sri Lanka.

\section{LITERATURE REVIEW}

\subsection{INFRASTRUCTURE DEVELOPMENTS}

New infrastructure developments would be located in developing countries, which consist of many of the world's most biologically rich and ecologically sensitive ecosystems (Grumbine et al., 2018). To achieve sustainable output from highly invested infrastructure developments in the $21^{\text {st }}$ century, people wanted to develop their nations, at the same time protecting the environment, preserve its existence, and doing less harm to society. That is why people have introduced environmental regulations and impact management instruments as an effort to mitigate environmental and sociological impacts (Finer and Jenkins, 2018). 


\subsection{EnVironmental Protection InStruments}

\subsubsection{EIA Survey}

The core purpose of the EIA survey is to establish the inseparable linkage between the environment and sustainable development (Hannayake et al., 2012). The EIA process recommends several steps and procedures for a project to reduce the negative environmental impacts and strengthen the positive environmental impacts (Hák et al., 2016). According to various researchers, five objectives of EIA were identified, which fall under several types of constructions and infrastructure development projects as given in Table 1.

Table 1: Purposes of EIA

\begin{tabular}{ll}
\hline \multicolumn{1}{c}{ Purpose } & \multicolumn{1}{c}{ Source } \\
\hline Control of projects and their environmental impacts & (Arts and Saunders, 2014) \\
$\begin{array}{l}\text { Promote an adaptive management approach and maintain } \\
\text { decision making flexibility }\end{array}$ & (Gangolells et al., 2009) \\
Improve technical and scientific knowledge & (Fadl and Fadel, 2014) \\
Improve public acceptance and awareness & (Fadl and Fadel, 2014) \\
\hline
\end{tabular}

\subsubsection{IEE}

IEE is a short and simple study, which is applied for the projects, with less environmental impacts, while the EIA is considered as a full assessment of the effects of a project with high environmental impacts (CEA, 2013). The main objectives of an IEE study are to identify the biophysical, socio-economic and cultural environment; identify, predict and evaluate, possible beneficial and adverse impacts; and finally recommend environmental mitigation and enhancement measures along with environmental monitoring requirements, which are practical and site-specific for a proposed development project (Bhatt, 2013).

\subsubsection{EPL Process}

EPL is a regulatory document under NEA to control the discharge of effluents, depositions of wastes, emission of smoke/gases, or excessive noise/vibration into the environment by construction activities (NEA, 2000). EPL processes have been interrelated with the EIA, IEE procedures within the construction and development processes (Environmental Pollution and Control Division, 2009). Obtaining an EPL through the approved procedure is the major requirement of a recognised EPL (Environmental Pollution and Control Division, 2009).

\subsection{ADOPTION OF EIA, IEE AND EPL IN SRI LANKA}

In 1981, the EIA was first introduced to Sri Lanka under the Coast Conservation Act, No. 57 of 1981 (Hannayake et al., 2012). EIA, IEE and EPL for the entire country were introduced by the National Environmental (Amendment) Act No.56 of 1988 (Hapuarachchi et al., 2016). The first EIA was conducted in Sri Lanka for the Accelerated Mahaweli Development Project in 1980 (Sivaramanan, 2017). Between 1981 and 2005, there were more than 460 EIAs and IEEs completed, within Sri Lanka, and most of them $(87 \%)$ were carried out under the NEA and just $6 \%$ of the EIAs and IEEs were carried out under the North-western Provincial Environmental Statute (NWPES) and 5\% of them 
under the Coast Conservation Acts and remaining 3\% under the Asian Development Bank and World Bank regulations (Samarakoon and Rowan, 2008).

\subsection{Procedure OF EIA ANd IEE IN SRI LaNKa}

The EIA procedure is compulsory for projects, which are located in ecologically sensitive areas and also for mega-developments projects in Sri Lanka (Gunawardena, 2000). The EIA process is applied only to "Prescribed Projects" and executed through a nominated Project Approving Agency (PAA), under the provision of section 23Z of the NEA, which has been specified by the Minister of Environment (GOSL, 1995). In Sri Lanka, the EIA and IEE process could be considered as a very simple and straightforward process and it includes six major steps of Environmental Impact Assessment (Environmental Impact Assessment Unit, 2006).

1. Preliminary information - The initial stage of the EIA and IEE process, which will lead to the key decision, either carrying out an assessment or not. This stage initiates with the submission of preliminary information about the prescribed development project by a Project Proponent (PP) (International Institute for Sustainable Development, 2020).

2. Environmental Scoping - This is a key step in preparing an EIA and IEE because it could identify the most important issues in the EIA and IEE process and eliminate those that are less important (Fadl and Fadel, 2014).

3. EIA, IEE Report Preparation - The EIA and IEE report is a summary of several key important project components, including project description, social and environmental impact assessments, mitigation measures, and related management and monitoring plans. In this step, all the data collected in the previous steps is composed into a detailed and comprehensive report, which will analyse and synthesise the data according to the requirements (Amato et al., 2017).

4. Public Participation (only for EIA) and Evaluation of the Report - The evaluation report shall be performed to validate the accuracy of the information and procedures used in the EIA and to ensure that all relevant mitigation steps and all accumulated and essential impacts are addressed in the EIA report (Wijayadasa, 1994).

5. Decision Making - PAA determines whether to approve the project based on the Technical evaluation committee's recommendation and if the PAA is not the CEA, the CEA permission should be obtained prior to granting approval (CEA, 2013).

6. Compliance Monitoring - Compliance monitoring provides details on the social and environmental impacts of the project over the entire life cycle of the project (Su et al., 2017).

\subsection{LEGAL FRAMEWORK ON EIA, IEE AND EPL IN SRI LANKA}

Sri Lankan Parliament enacted legislation on environmental protection, spanning over two centuries that took the form of royal decrees and customary law (Weeramantry, 1997). Afterward various environmental regulations implemented by the British rulers continue to be applied and enforced. Currently, four environmental assessment legislation have been implemented mainly, and four institutions are in charge of these legislation (Liyanawatte and Dias, 2017). 
They are namely:

- Central Environmental Authority in charge of the National Environmental Act (NEA, 1988) - NEA is enacted to serve as the main legislation for environmental protection. The EIA, IEE and EPL instruments were introduced by the NEA, in order to drive sustainable developments for the entire country.

- Department of Coast Conservation in charge of the Coast Conservation Act (CCA, 1981) - EIA was first introduced by the Coast Conservation Act. The "Coastal zone" includes areas with an average high-water level of 300 meters and an average low water level of 2 kilometres. CCA requests developers applying for a permit (activities in the coastal zone) to provide EIA, IEE related to the development project. According to CCD, EIA must be carried out when the effect of the project is significant and also the constructions cannot be carried out in "No Build Areas".

- North-western Provincial Council in charge of the North-western Provincial Council Environmental Statute (NWPES, 1990) - Only the Northwestern Province (NWP) in Sri Lanka has enacted a provincial statute that supersedes the writ of NEA in that province. Legal provision for EIA, IEE and EPL in the NWP is given by the NWPES. The EIA and IEE procedure and the EPL procedure have been combined, within NWP according to NWPES.

- Department of Wildlife Conservation in charge of the Flora and Fauna (Amended) Act (FFA, 1993) - Any construction project that is supposed to be carried out within one mile of the boundary of any national reserve must be subject to an EIA. Clients should obtain written approval from the Director-General of the Department of Wildlife Conservation before implementing such projects.

\section{RESEARCH METHODOLOGY}

For this research, a mixed approach was adopted due to the requirement of assessing subjective data as expert's opinions and identify the level of significance as questionnaire survey responding levels. When collecting data from the experts all the relevant parties were involved. Similarly, due to the sensitivity of the environmental data, the semistructured interviews were carried out not only with the construction experts but also with a legal expert, an environmental expert, NGO personnel involved in environmental matters, and an expert in the government sector involved in environmental matters, who have more than 10 years of experience. In the first stage, six expert interviews were carried out to achieve targets such as for the confirmation of suitability of identified challenges and issues of EIA, IEE, and EPL under three subcategories such as challenges and issues related to, legislation and regulatory agencies, the current performance of EIA, IEE and EPL in Sri Lanka and through literature review. The research was received 40 responses from a questionnaire survey out of 46 , in order to identify the level of significance of each challenge and issue related to EIA, IEE, and EPL instruments.

In this research, preliminary interview results were analysed through manual content analysis. Parametric tests were selected as data analysis techniques of the questionnaire survey. Minitab 17 software was used to analyse the questionnaire survey data to achieve the main objective of the questionnaire survey. Suggestions and recommendations which had been given by experts at stage - II were analysed using content analysis which was done using NVIVO software version 12. Figure 1 illustrates the data collection methods used for the study. 


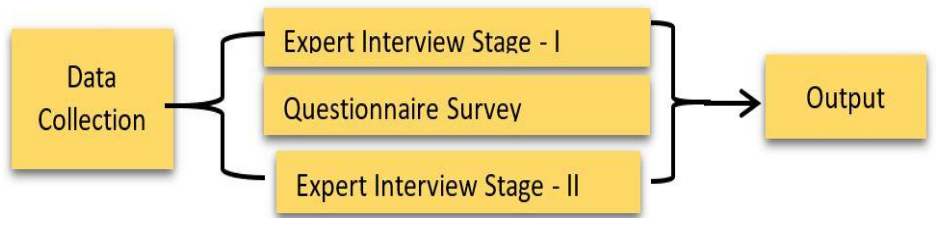

Figure 1: Data collection

\section{RESEARCH FINDINGS}

\subsection{DETAILS OF RESPONDENTS}

Table 2 provides the details of the experts who were involved in the expert interview stages I and II.

Table 2: Details of interviewees for expert interview stages I and II

\begin{tabular}{clcl}
\hline Interviewee & \multicolumn{1}{c}{ Profession } & $\begin{array}{c}\text { Years of } \\
\text { Experience }\end{array}$ & \multicolumn{1}{c}{ Field } \\
& Chartered Quantity Surveyor & 15 & $\begin{array}{l}\text { Construction (Specialised in } \\
\text { Infrastructure Developments) }\end{array}$ \\
E2 & Chartered Quantity Surveyor & 12 & \\
E3 & Chartered Civil Engineer & 16 & Legal Field -specialised for \\
E4 & Lawyer/Former Legal Manager & 10 & EIA/IEE and EPL related cases \\
& engaging in environmental-related & & Government \\
& activism & 10 & Environment \\
E5 & Director in a government body & 18 & \\
\hline
\end{tabular}

The quantitative analysis was carried out using the data collected from the results of the questionnaire survey and it was distributed to 46 experts in serval industries and 40 experts replied to the questionnaire (refer Table 3).

Table 3: Respondents of the questionnaire survey

\begin{tabular}{|c|c|c|c|c|c|c|}
\hline \multirow[b]{2}{*}{ Designation of the respondents } & \multicolumn{5}{|c|}{ Years of Experience } & \multirow[b]{2}{*}{$\begin{array}{l}\text { Number of } \\
\text { Respondents }\end{array}$} \\
\hline & $\frac{e}{e}$ & $\begin{array}{l}\frac{10}{8} \\
\stackrel{0}{0}\end{array}$ & $\begin{array}{c}\stackrel{7}{7} \\
9 \\
10 \\
=\end{array}$ & $\begin{array}{l}\stackrel{n}{N} \\
\stackrel{8}{8} \\
\stackrel{2}{1}\end{array}$ & 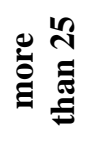 & \\
\hline Quantity Surveyor & 7 & 3 & 3 & 1 & & 14 \\
\hline Project Manager & 2 & 2 & 1 & & 3 & 8 \\
\hline Construction Manager & 3 & & 2 & 2 & & 7 \\
\hline Legal Experts & & 2 & 1 & & & 3 \\
\hline Environmentalists & & 2 & & & 2 & 4 \\
\hline Members in NGOs involved in environmental matters & 1 & 1 & & & & 2 \\
\hline \multirow[t]{4}{*}{ Relevant officials in government institutions } & & 1 & 1 & & & 2 \\
\hline & \multicolumn{5}{|c|}{ Total Responses } & 40 \\
\hline & \multicolumn{5}{|c|}{ Total Distributed } & 46 \\
\hline & \multicolumn{5}{|c|}{ Rate of Response } & $87 \%$ \\
\hline
\end{tabular}




\subsection{CHALLENGES AND ISSUES RELATED TO EIA, IEE AND EPL IN SRI LANKA}

According to the literature findings, seventeen challenges and issues related to EIA, IEE, and EPL were identified. Those challenges and issues are,

- Related to legislation and regulatory agencies of EIA, IEE, and EPL in Sri Lanka

- Related to the current Performance of EIA, IEE, and EPL in Sri Lanka

- Related to the process of EIA, IEE and EPL in Sri Lanka.

After the expert interview stage - I, those challenges and issues were refined according to the level of relevance provided by each expert. According to the experts, four challenges and issues were eliminated from the literature findings and ten new facts were added and those refined twenty-three factors were listed out in the questionnaire survey to derive the level of significance of each factor. In the questionnaire survey, the experts have presented their responses. In this way, their opinions regarding the questionnaire were analysed, and the opinions were reviewed utilising the RII method. Five important levels are transformed from RII values as given in Table 4: high $(\mathrm{H})(0.8 \leq \mathrm{RII} \leq 1)$, highmedium $(\mathrm{H}-10 \mathrm{M})(0.6 \leq \mathrm{RII} \leq 0.8)$, medium $(\mathrm{M})(0.4 \leq \mathrm{RII} \leq 0.6)$, medium-low (M-L) $(0.2 \leq \mathrm{RII} \leq 0.4)$ and low $(\mathrm{L})(0 \leq \mathrm{RII} \leq 0.2)$ (Taherdoost, 2016).

\subsection{CHALLENGES AND ISSUES RELATED TO LEGISLATION AND REGULATORY AGENCIES}

Table 4 illustrates the derived analysis results for the facts of challenges and issues related to legislation and regulatory agencies of EIA, IEE and EPL. Data analysis was done in Minitab 17 software. It shows the RII values for individual causes in descending order with their ranks.

The first rank received "Loopholes due to the list of prescribed projects (RII 0.92)", and it is the most significant cause according to the analysis results. Over $60 \%$ of experts marked scale as "Strongly agree" for this cause. All these eight factors are challenges and issues related to legislation and regulatory bodies, and the level of their significance are differing with RII values.

"Shortcomings and constraints in provisions for the public review by the gazette" took the second-highest RII value (RII 0.87) among eight factors. The third highest RII value (RII 0.76) was received by the factor of "Lack of apprehension provisions for EIA, IEE and EPL violators". In addition to that "Inadequacy of provisions in the NEA for PAA" and "Lack of qualified staff in CEA and CCD" factors received the lesser level of significance with 0.49 and 0.55 of RIIs respectively.

Table 4: Results of challenges and issues related to legislation and regulatory agencies of EIA, IEE and EPL

\begin{tabular}{lllcl}
\hline No & $\begin{array}{l}\text { Challenges and issues related to legislation and } \\
\text { regulatory agencies }\end{array}$ & RII & Rank & $\begin{array}{c}\text { Level of } \\
\text { Significance }\end{array}$ \\
\hline 1 & $\begin{array}{l}\text { Loopholes due to the list of prescribed projects } \\
2\end{array}$ & 0.92 & 1 & High \\
& $\begin{array}{l}\text { Shortcomings and constraints in provisions for the } \\
\text { public review by the gazette }\end{array}$ & 0.88 & 2 & High \\
3 & $\begin{array}{l}\text { Lack of apprehension provisions for EIA, IEE and } \\
\text { EPL violators }\end{array}$ & 0.76 & 3 & High-medium \\
\end{tabular}




\begin{tabular}{clccc}
\hline No & $\begin{array}{l}\text { Challenges and issues related to legislation and } \\
\text { regulatory agencies }\end{array}$ & $\begin{array}{l}\text { RII } \\
\quad \text { Rank }\end{array}$ & $\begin{array}{c}\text { Level of } \\
\text { Significance }\end{array}$ \\
\hline 4 & $\begin{array}{l}\text { Enforcement of separate statute for the North- } \\
\text { western Province instead of NEA }\end{array}$ & 0.68 & 4 & High-medium \\
5 & $\begin{array}{l}\text { Lack of guidance, given by the CEA to PP (client) } \\
\text { in EIA, IEE, or EPL }\end{array}$ & 0.65 & 5 & High-medium \\
$6 \quad \begin{array}{l}\text { Improper guidance of CEA for a proper EIA, IEE } \\
\text { and EPL implementation }\end{array}$ & 0.61 & 6 & High-medium \\
7 & $\begin{array}{l}\text { Inadequacy of provisions in the NEA for PAA } \\
8\end{array}$ & 0.55 & 7 & Medium \\
\hline
\end{tabular}

\subsection{Challenges And Issues Related to the Current Performance OF EIA, IEE AND EPL IN SRI LANKA}

One to eight causes were analysed and derived their RII values. Table 5 indicates the evaluated results in descending order. The level of significance is indicating their RII values and ranks.

Table 5: Challenges and issues related to the current performance of EIA, IEE and EPL in Sri Lanka

\begin{tabular}{llccc}
\hline No & $\begin{array}{c}\text { Challenges and issues related to the current } \\
\text { performance of EIA, IEE, and }\end{array}$ & RII & Rank & $\begin{array}{c}\text { Level of } \\
\text { Significance }\end{array}$ \\
\hline 1 & $\begin{array}{l}\text { Inadequate post EIA, IEE, and EPL monitoring } \\
2\end{array}$ & 0.95 & 1 & High \\
3 & $\begin{array}{l}\text { Problems with existing environmental data } \\
\text { The inability of identifying the cumulative impact } \\
\text { of multiple projects in an area }\end{array}$ & 0.87 & 2 & High \\
4 & Less consideration on reasonable alternatives & 0.83 & 4 & High \\
5 & $\begin{array}{l}\text { Unavailability of quality, technical and procedural } \\
\text { guidelines for the processes }\end{array}$ & 0.80 & 5 & High \\
6 & $\begin{array}{l}\text { Low quality of the reports, produced by the } \\
\text { current EIA, IEE and EPL mechanisms }\end{array}$ & 0.76 & 6 & High-medium \\
7 & $\begin{array}{l}\text { Lack of public awareness } \\
8\end{array}$ & 0.73 & 7 & High-medium \\
& EIA and IEE always govern a reactive & 0.67 & 8 & High-medium \\
\hline
\end{tabular}

The highest RII value of 0.95 was taken "Inadequate post EIA, IEE and EPL monitoring" and it is marked as rank one. Likewise, over $70 \%$ of experts marked scale as "Strongly agree" for this cause. That is the most significant issue related to the current performance of EIA, IEE and EPL in Sri Lanka. Rank two with an RII value of 0.88 had been taken by both "Problems with existing environmental data" and "Inability of identifying the cumulative impact of multiple projects in an area" factors.

\subsection{Challenges and Issues related to the Process of EIA, IEE AND EPL IN SRI LANKA}

There are seven factors for challenges and issues related to the process of EIA, IEE and EPL in Sri Lanka. Those results were computed through Minitab 17 and a summary is presented in Table 6 in descending order. 
Table 6: Results of challenges and issues related to the process of EIA, IEE and EPL in Sri Lanka

\begin{tabular}{llccc}
\hline No & $\begin{array}{l}\text { Challenges and issues related to the process of } \\
\text { EIA, IEE and EPL in Sri Lanka }\end{array}$ & RII & Rank & $\begin{array}{c}\text { Level of } \\
\text { Significance }\end{array}$ \\
\hline 1 & $\begin{array}{l}\text { Influences of the politics to EIA, IEE and EPL } \\
\text { processes }\end{array}$ & 0.93 & 1 & High \\
2 & $\begin{array}{l}\text { Inadequacy of funds to run many of the PAAs and } \\
\text { other EIA cells }\end{array}$ & 0.83 & 2 & High \\
3 & Lack of professional ethics of EIA consultants & 0.80 & 3 & High \\
4 & Conflicts of interests for the PAA & 0.75 & 4 & High-medium \\
5 & Lack of tolerance standards & 0.72 & 5 & High-medium \\
6 & The limited time frame which is given for PAAs & 0.70 & 6 & High-medium \\
7 & Influences due to various economic aspects & 0.63 & 7 & High-medium \\
\hline
\end{tabular}

"Influences of the politics to EIA, IEE and EPL processes" (RII 0.93) received the rank one, and it is the most significant cause in this category. Over $70 \%$ of experts marked scale as "Strongly Agree" for that cause. the rank two was taken for "Inadequacy of funds to run many of the PAAs and other EIA cells" with an RII value of 0.83 . Accordingly, "Lack of professional ethics of EIA consultants" took the third-highest position (RII $0.80)$.

\subsection{REMEdiES TO OVERCOME THE ChallengeS AND ISSUES}

According to the similar phenomena that have been identified from the previous research carried out in several countries, the solutions were introduced for the most significant top five challenges and issues related to environmental protection regulatory instruments. Therefore, in this research, also the most significant top-five ranked challenges and issues which were ranked using RII were derived to identify recommendations from the experts. For that, an expert interview stage II was carried out.

After analysing challenges, suitable solutions to overcome the most significant challenges were discovered under the expert interviews - stage II. The expert who was interviewed initially (E1), was given a chance to provide suggestions and recommendations for the challenges and issues, commonly for each category, and for the challenges specifically mentioned by him. After E1, all other interviewees were asked for providing solutions for the major challenges and issues identified under each subcategory. Likewise, the following solutions were generally identified and agreed upon by the experts under each category of challenges and issues.

Table 7 elaborates nineteen (19) suggestions and the number of references for each, that were identified for mitigation of challenges and issues. Suggestions with a greater number of references according to NVivo analysis could be identified as more vital facts. 
Table 7: Suggestions to overcome the challenges and issues

\begin{tabular}{|c|c|c|}
\hline $\begin{array}{l}\text { Category of } \\
\text { challenges and } \\
\text { issues }\end{array}$ & Suggestions to mitigate & $\begin{array}{c}\text { No of } \\
\text { References }\end{array}$ \\
\hline \multirow{5}{*}{$\begin{array}{l}\text { Challenges and } \\
\text { issues related to } \\
\text { legislation and } \\
\text { regulatory } \\
\text { agencies }\end{array}$} & $\begin{array}{l}\text { 1. The list of projects prescribed and the limitations } \\
\text { should be reduced }\end{array}$ & $6(6)$ \\
\hline & $\begin{array}{l}\text { 2. The time allocated for public review and involvement } \\
\text { especially for complex development projects should be } \\
\text { increased }\end{array}$ & $5(6)$ \\
\hline & $\begin{array}{l}\text { 3. Strictly enforce apprehension provisions for people } \\
\text { who bypass EIA, IEE and EPL procedures }\end{array}$ & $6(6)$ \\
\hline & $\begin{array}{l}\text { 4. Quality and technical guidelines should be prepared } \\
\text { and make available to get proper guidance for the } \\
\text { employers when implementing a construction project }\end{array}$ & $4(6)$ \\
\hline & $\begin{array}{l}\text { 5. NWPES should be abolished and NEA should be } \\
\text { enforced for the whole country }\end{array}$ & $6(6)$ \\
\hline \multirow{8}{*}{$\begin{array}{l}\text { Challenges and } \\
\text { issues related to } \\
\text { the current } \\
\text { performance of } \\
\text { EIA, IEE, and } \\
\text { EPL in Sri } \\
\text { Lanka }\end{array}$} & $\begin{array}{l}\text { 6. Environmental cells of the PAA should be occupied } \\
\text { with, full-time talented staff and other related facilities } \\
\text { which are required for proper EIA and IEE monitoring }\end{array}$ & $4(6)$ \\
\hline & $\begin{array}{l}\text { 7. The environmental data which are required for the } \\
\text { EIA/ IEE and EPL procedures should be accumulated } \\
\text { and made available to the relevant PP and EIA and IEE } \\
\text { consultants by the relevant PAA }\end{array}$ & $5(6)$ \\
\hline & $\begin{array}{l}\text { 8. The environmental data limitations and shortcomings } \\
\text { must be highlighted by the CEA and the actions must } \\
\text { be taken to obtain them }\end{array}$ & $3(6)$ \\
\hline & $\begin{array}{l}\text { 9. The PAA should develop a scheme of taxes or levies to } \\
\text { cover up the costs related to EIA and IEE }\end{array}$ & $2(6)$ \\
\hline & $\begin{array}{l}\text { 10. Identification of the types of development projects to } \\
\text { be promoted in each region and implemented within } \\
\text { the country with the intercession of the CEA }\end{array}$ & $5(6)$ \\
\hline & $\begin{array}{l}\text { 11. Areas to be reserved for environmental conservation } \\
\text { and industries should be zoned within the country }\end{array}$ & $4(6)$ \\
\hline & $\begin{array}{l}\text { 12. The provisions for multiple PAAs, in the NEA, should } \\
\text { be followed in the case of multi-sector infrastructure } \\
\text { development projects }\end{array}$ & $4(6)$ \\
\hline & $\begin{array}{l}\text { 13. All officials in the EIA, IEE and EPL should be aware } \\
\text { of all environmental aspects of project appraisal }\end{array}$ & $5(6)$ \\
\hline \multirow{2}{*}{$\begin{array}{l}\text { Challenges and } \\
\text { issues related to } \\
\text { the process of } \\
\text { EIA, IEE and } \\
\text { EPL in Sri } \\
\text { Lanka }\end{array}$} & $\begin{array}{l}\text { 14. The regulations related to EIA and IEE procedures } \\
\text { have to be strengthened and expanded in order to give } \\
\text { more supervision on infrastructure developments }\end{array}$ & $4(6)$ \\
\hline & $\begin{array}{l}\text { 15. Proper safeguards such as improved transparency must } \\
\text { be in place to make sure that the Project Approving } \\
\text { Agencies are not inattentive or politically influenced }\end{array}$ & $5(6)$ \\
\hline
\end{tabular}




\begin{tabular}{ccc}
\hline $\begin{array}{c}\text { Category of } \\
\text { challenges and } \\
\text { issues }\end{array}$ & \multicolumn{1}{c}{ Suggestions to mitigate } & $\begin{array}{c}\text { No of } \\
\text { References }\end{array}$ \\
\hline & $\begin{array}{l}\text { 16. Financial problems and difficulties have to be } \\
\text { overcome by levies, which make the client and the } \\
\text { government 50\% to 50\% for essential services }\end{array}$ & $\mathbf{5 ( 6 )}$ \\
& $\begin{array}{l}\text { 17. A proper mechanism should be introduced to monitor } \\
\text { the unethical actions of EIA consultants }\end{array}$ & $2(6)$ \\
& $\begin{array}{l}\text { 18. } \begin{array}{l}\text { The CEA should develop a code of conduct for EIA } \\
\text { and IEE consultants with the help of suitable } \\
\text { professional bodies }\end{array} \\
\text { 19. } \begin{array}{l}\text { The tolerance standards which have been given by the } \\
\text { CEA for the discharge of construction wastes should be } \\
\text { amended as a more comprehensive outcome }\end{array}\end{array}$ & $3(6)$ \\
\hline
\end{tabular}

\section{CONCLUSIONS AND RECOMMENDATIONS}

The construction industry can be considered a highly contributing sector in the economy of a country. When considered the Sri Lankan construction industry, currently there are many infrastructure development projects are being carried out in order to fulfil the requirements of a rapidly growing population. Due to this rapidly growing requirement of infrastructure development projects, there is also an increasing huge adverse impact on the environment by the constructions. With the intention of regulating this issue, the Sri Lankan government has introduced several legislations and controlling bodies to implement several worlds recognized environmental protection regulatory instruments in order to regulate the adverse impacts on the environment by the construction industry and pushing them towards the expected sustainable outcome. EIA, IEE, and EPL are the main instruments that could be identified as environmental protection (regulatory) instruments in Sri Lanka. According to the research, recommendations that were identified, it would recommend the following areas to overcome challenges and issues of EIA, IEE, and EPL related to infrastructure development projects in Sri Lanka:

- The current list of prescribed projects which are interpreted in NEA should be expanded and strictly enforce apprehension provisions and laws for people who bypass EIA, IEE, and EPL procedures.

- NWPES should be abolished and NEA should be enforced for the whole country

- The all the relevant environmental data which are required for an EIA, IEE, and EPL should be collected by the relevant PAA for the ease of the clients.

- Financial difficulties of regulatory bodies and PAAs should be sorted out by levies, which should not only be applied to clients but also to the government $50 \%$ to $50 \%$.

- There should be proper safeguards to make sure that the Project Approving Agencies are not inattentive or politically influenced.

- The CEA must provide proper guidance when implementing EIA, IEE, and EPL instruments and especially should implement post-monitoring mechanisms effectively. 


\section{REFERENCES}

Arts and Saunders, 2014. International principles for best practice EIA follow-up. Impact Assessment and Project Appraisal, 23(3), pp. 175-181.

Abidin, N.Z. and Pasquire, C.L., 2005. Delivering sustainability through value management. Engineering, Construction and Architectural Management, 12(2), pp. 168-180.

Bhatt, R.P., 2013. Initial Environmental Examination (IEE) for Construction of New Bank Protection Work and Spurs in Lothar of East Rapti, Kathmandu: Ministry of Forests and Soil Conservation Nepal.

Cashmore, M. Gwilliam, R., Morgan, R., Cobb, D. and Bondet, A., 2015. The interminable issue of effectiveness: Substantive purposes, outcomes and research challenges in the advancement of environmental impact assessment theory. Impact Assessment and Project Appraisal, 22(4), pp. 295310.

Dulac, J., 2013. Global land transport infrastructure requirements, Paris: International Energy Agency.

Environmental Impact Assessment Unit, 2006. Guidance for implementing the environmental impact assessment (EIA) process; No 2: A general guide for conducting environmental scoping. 3rd ed. Battaramulla: Central Environmental Authority.

Fadl, K. and Fadel, M., 2014. Comparative assessment of EIA systems in MENA countries: challenges and prospects.. Environmental impact assessment review, 24(6), pp. 553-593.

FFA, 1993. Flora and Fauna (Amended) Act No. 49 (1993), Government of Sri Lanka.

Finer, M. and Jenkins, C.N., 2018. The proliferation of hydroelectric dams in the Andean Amazon and implications for Andes-amazon connectivity. PLoS ONE, 7(4), pp. 1-9.

Gangolells, M., Casals, M., Gasso, S. and Forcada, N., 2009. A methodology for predicting the severity of environmental impacts related to the construction process of residential buildings. Building and Environment, 44(3), pp. 558-571.

Grumbine, R.E., Dore, J. and Xu, J., 2018. Mekong hydropower: drivers of change and governance challenges. Frontiers in Ecology and the Environment, 10(2), pp. 91-98.

Gunawardena, M.P., 2000. A Critical Review of Environmental Impact.

Hannayake, S.K., Smythe, R., Hewage, A. and Ellepola, R., 2012. Simple questions and answers on Environmental Impact Assessment (EIA). $3^{\text {rd }}$ ed. Colombo: Central Environmental Authority.

Hapuarachchi, A.B., Hughey, K. and Rennie, H., 2016. Effectiveness of Environmental Impact Assessment (EIA) in addressing development-induced disasters: a comparison of the EIA processes of Sri Lanka and New Zealand. Natural Hazards, 81(1), pp. 423-445.

Lenferink, S., Tillema , T. and Arts, J., 2013. Towards sustainable infrastructure development through integrated contracts: Experiences with inclusiveness in Dutch infrastructure projects. International Journal of Project Management, 31(4), pp. 615-627.

Liyanawatte , C.V. and Dias, K.G., 2017. Analysis on deforestation and environmental law in Sri Lanka., Rathmalana: General Sir John Kotelawala Defence University.

NEA, 1988. National Environmental Act No: 47 of 1980 amended by Acts No 56 of 1988, Government of Sri Lanka.

NWPES, 1990. North Western Province Environmental Statute No. 12 of 1990.

Ofori, G., 1990. The construction industry: aspects of its economics and management. NUS Press.

Sivaramanan, S., 2017. The Accelerated Mahaweli Development Project and Environmental activities were undertaken as a consequence of this EIA in the Wildlife Sector., Maradana: Mahaweli Authority of Sri Lanka.

Su, S., Li, X., Zhu, Y. and Lin, B., 2017. Dynamic LCA framework for environmental impact assessment of buildings. Energy and Buildings, 149, pp. 310-320.

Weeramantry, C.G., 1997. Gabcikovo-Nagymaros Project. International Court of Justice.

Wijayadasa, K.J., 1994. Towards sustainable growth; The Sri Lanka experience. $2^{\text {nd }}$ ed. Battaramulla: Central Environmental Authority.

Zubair, L., 2001. Challenges for environmental impact assessment in Sri Lanka. Environmental Impact Assessment Review, 21(5), pp. 469-478. 